\title{
Kinetics of Glucose Disposal in Whole Body and Across the Forearm in Man
}

\author{
Hannele Yki-Järvinen, Andrew A. Young, Carol Lamkin, and James E. Foley \\ Clinical Diabetes and Nutrition Section, National Institutes of Health, National Institute of Diabetes, Digestive Diseases and Kidney \\ Diseases, Phoenix, Arizona 85016
}

\begin{abstract}
We reevaluated the concept that the in vivo glucose disposal rate in man is determined by the activity of the glucose transport system. Rates of glucose disposal were determined in whole body and across forearm at four insulin levels $(\sim 9, \sim 50, \sim 160$, and $\sim 1700 \mu \mathrm{U} / \mathrm{ml})$ and at each insulin level at four glucose levels $(\sim 90, \sim 160, \sim 250$, and $\sim 400 \mathrm{mg} / \mathrm{dl})$. At the lowest insulin level, the Michaelis constants $\left(K_{z}: s\right)$ for glucose disposal in whole body $(8.7 \pm 1.1 \mathrm{mM})$ and across forearm $(7.4 \pm 1.4) \mathrm{mM})$ were compatible with a $K_{\mathrm{s}}$ determined in vitro for the transport system. At higher insulin levels, the apparent $K_{\mathrm{s}}$ increased significantly in whole body (16.2-37.7 $\mathrm{mM})$ and across forearm (20.7-31.2 $\mathrm{mM}$ ). We interpret the apparent increase of $K_{\mathrm{s}}$ by insulin to reflect a shift in the rate-limiting step from glucose transport to some step beyond transport.
\end{abstract}

\section{Introduction}

At present considerable controversy still exists regarding the ratelimiting steps for glucose disposal ${ }^{1}$ in man. It has generally been recognized that muscle is the major site of glucose disposal under hyperinsulinemic conditions (1). In muscle, insulin activates both glucose transport into the cell and its conversion to glycogen (2). It has been assumed that glucose transport is the rate-limiting step for glucose disposal by the muscle and that insulin regulation of this process is responsible for insulin's ability to increase glucose disposal. In isolated muscle, glucose transport has been shown to follow Michaelis-Menten kinetics $(3,4)$. In addition, the preponderance of data indicate that insulin's effect is to increase the maximum transport rate $\left(V_{\max }\right)$, probably by increasing the number of functional transporters in the cell membrane without changing the affinity of the transporter for glucose $\left(K_{\mathbf{s}}\right)$ (4). Gottesman et al. (5) showed that both basal and insulinstimulated rates of glucose disposal in vivo could be described using Michaelis-Menten kinetics with a constant $K_{\mathrm{s}}(8-12 \mathrm{mM})$ similar to that determined in isolated muscle. This data suggested

Address correspondence to Hannele Yki-Järvinen, M.D., Clinical Diabetes and Nutrition Section, National Institutes of Health, National Institute of Diabetes, Digestive Diseases and Kidney Diseases, $4212 \mathrm{~N}$. 16th St., Phoenix, AZ 85016.

Dr. Young's present address is Max-Planck Institut, D-6350 Bad Nauheim, FRG. Dr. Foley's present address is Sandoz Research Institute, East Hanover, NJ 07936.

Received for publication 14 October 1986 and in revised form 22 January 1987.

1. The term "disposal" is used throughout the text to describe the disappearance of glucose from plasma, but this does not necessarily imply intracellular glucose utilization, i.e., metabolism (see reference 6).

The Journal of Clinical Investigation, Inc.

Volume 79, June 1987, 1713-1719 that the assumption that glucose transport was the rate-limiting step for glucose disposal was well founded. However, kinetic analysis was performed over a range of glucose concentrations $(60-160 \mathrm{mg} / \mathrm{dl})$ in which demonstration of saturation could not be expected. Thus, any number of other models of glucose disposal could have been fitted to the data (Fig. 1).

In an in vivo study in man, Ferrannini et al. (6) recently showed that glucose distribution volume increases during insulin stimulation and suggested that this was due to accumulation of free intracellular glucose in insulin-dependent tissues. On the other hand, attempts to demonstrate an increase in intracellular free glucose by direct measurements in skeletal muscle have not been successful $(7,8)$. These measurements, however, depend upon the assumption that glucose is uniformly distributed throughout the cell $(7,8)$. Studies in adipocytes $(9)$ and smooth muscle (10) suggest that there may be compartmentalization of the cell with regard to sugars and sugar phosphates. Thus, the fundamental assumption that free glucose must be demonstrated intracellularly for steps other than transport to be rate limiting may not be valid.

Recently we demonstrated that under hyperglycemic or hyperinsulinemic conditions glucose transport is not the rate-limiting step for glucose disposal in the rat hindlimb (11). It might be possible therefore that a similar limitation of the capacity of muscle to metabolize glucose may exist in man.

In the present study we wanted to reevaluate the concept that whole body glucose disposal follows saturation kinetics of the Michaelis-Menten type with a $K_{\mathbf{s}}$ characteristic of glucose transport. This was done by measuring rates of glucose disposal over a wide range of glucose and insulin concentrations. To allow direct analysis of the role of muscle in determining the rate of whole-body glucose disposal under various hyperglycemic and/or hyperinsulinemic conditions, we made the glucose disposal measurements across forearm muscle simultaneously with those in the whole body. The results indicate that if high plasma glucose concentrations are included, during insulin stimulation glucose disposal cannot be described by saturation kinetics of the Michaelis-Menten type with a $K_{\mathrm{s}}$ characteristic of the glucose transport system.

\section{Methods}

Subjects and study protocol. 22 male Caucasian volunteers were admitted to the metabolic ward of Clinical Diabetes and Nutrition Section for study. The subjects resided at the research ward throughout a 15-d study period. After written informed consent was obtained, all subjects were physically examined and a 12-lead electrocardiogram recorded. After an overnight fast, blood was drawn for complete blood count, liver function tests, blood-urea nitrogen, creatinine, electrolytes, calcium, total protein, and albumin. None of the subjects was taking any medications and all had a normal physical examination, electrocardiogram, and blood tests. After $3 \mathrm{~d}$ on a weight-maintaining diet containing at least $200 \mathrm{~g}$ of carbohydrate per day, a 3-h oral glucose tolerance test (12) was performed. The percent body fat of each volunteer was determined by underwater 
Rd vs. Glucose

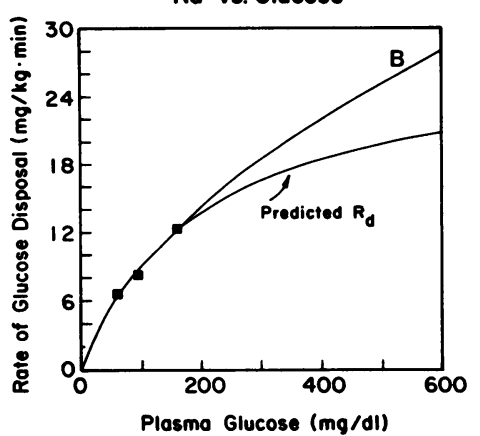

Figure 1. Prediction of glucose disposal rates in whole body from measurements in the glucose range $60-160$ $\mathrm{mg} / \mathrm{dl}$ by Gottesman et al. (5). (घ) Mean rates of glucose disposal found by Gottesman et al. (10) at the highest insulin level (160 $\mu \mathrm{U} / \mathrm{ml})$. Curve $B$ represents another equally good fit for the data.

weighing with correction for the simultaneously measured residual lung volume by helium dilution (13).

A total of 88 glucose disposal measurements were performed at four different glucose concentrations on separate days (days 5, 8, 11, and 14 from admission) in the 22 subjects. Thus, each subject participated in four studies. In all four studies, each subject received the same insulin dose but plasma glucose was maintained at either $90,160,250$, or 400 $\mathrm{mg} / \mathrm{dl}$ (Fig. 2). The order of studies at the different glucose levels was randomized. The subjects were divided into four groups, which received insulin at infusion rates of $0(n=6), 20(n=5), 60(n=6)$, or $400(n$ $=5) \mathrm{mU} / \mathrm{m}^{2} \cdot \mathrm{min}$. The subgroups differing with respect to the insulin infusion rate were matched for age, body weight, and composition, and for glucose and insulin levels during the oral glucose tolerance test (Table I). Each subject had normal glucose tolerance.

Glucose disposal measurements. Following an overnight fast three catheters were inserted. Catheter 1 was placed in an antecubital vein for infusion of glucose, somatostatin, [3- $\left.\mathrm{H}^{3}\right]$ glucose and insulin. Catheter 2 was inserted in an ipsilateral heated dorsal hand vein for sampling of arterialized venous blood (14). The use of a heated superficial hand vein as a replacement for an artery has been previously validated for measurement of glucose kinetics in man $(14,15)$. Catheter 3 was threaded into the contralateral arm in the deep branch of the median cubital vein for sampling of blood draining the forearm muscle (16). The protocol for the infusions and infusion rates used to measure glucose disposal at different glucose and insulin levels is diagrammed in Fig. 2. The insulin infusions (porcine monocomponent insulin, Nordisk-USA, Bethesda, MD) were given in a primed continuous manner as previously described $(2,17)$. Somatostatin (Sigma Chemical Co., St. Louis, MO) was infused

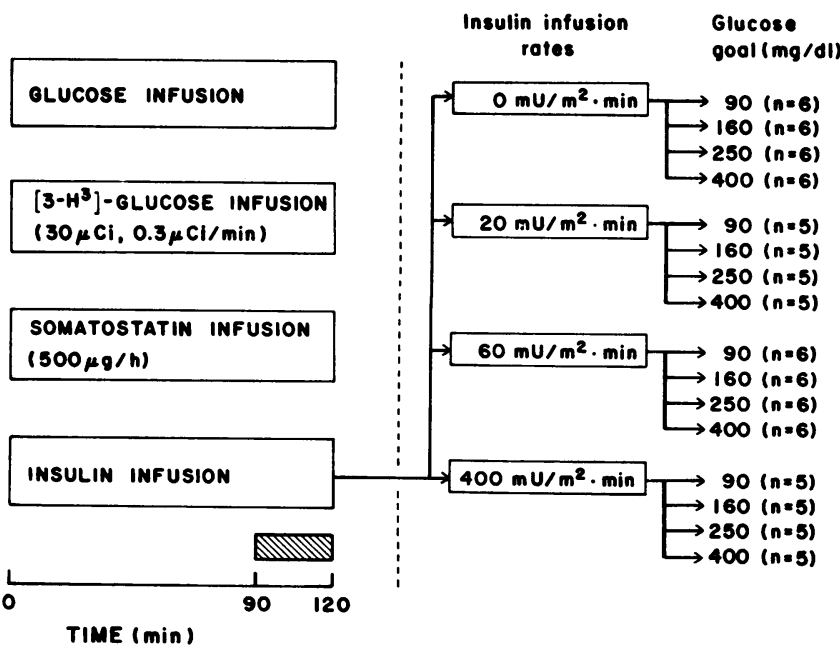

Figure 2. Design of the study. Hatched area denotes the time period for the blood flow measurements.

Table I. Characteristics of Subjects

\begin{tabular}{|c|c|c|c|c|}
\hline & \multicolumn{4}{|c|}{ Insulin infusion rate $\left(\mathrm{mU} / \mathrm{m}^{2} \cdot \mathrm{min}\right)$} \\
\hline & 0 & 20 & 60 & 400 \\
\hline$n$ & 6 & 5 & 6 & 5 \\
\hline Age $y r$ & $27 \pm 2$ & $28 \pm 2$ & $29 \pm 2$ & $28 \pm 2$ \\
\hline \multicolumn{5}{|c|}{ Body mass index } \\
\hline $\mathrm{kg} / \mathrm{m}^{2}$ & $23.1 \pm 1.4$ & $23.8 \pm 1.1$ & $21.7 \pm 1.1$ & $21.2 \pm 1.0$ \\
\hline Fat $\%$ & $15 \pm 4$ & $17 \pm 3$ & $17 \pm 3$ & $14 \pm 3$ \\
\hline \multicolumn{5}{|c|}{ Fasting glucose } \\
\hline $\begin{array}{c}m g / d l \\
2 \mathrm{~h} \text {.glucose }\end{array}$ & $91 \pm 2$ & $86 \pm 4$ & $90 \pm 2$ & $92 \pm 2$ \\
\hline $\begin{array}{c}m g / d l \\
\text { Fasting ins }\end{array}$ & $106 \pm 14$ & $106 \pm 7$ & $94 \pm 9$ & $109 \pm 5$ \\
\hline $\begin{array}{c}\mu U / m l \\
2 \mathrm{~h} \text { insulin }\end{array}$ & $16 \pm 2$ & $14 \pm 1$ & $15 \pm 2$ & $18 \pm 2$ \\
\hline$\mu U / m l$ & $78 \pm 12$ & $68 \pm 30$ & $37 \pm 9$ & $60 \pm 13$ \\
\hline
\end{tabular}

Results are expressed as means \pm SEM.

in all studies to suppress endogenous insulin secretion (Fig. 2). Plasma glucose was adjusted to the desired level within 0-30 min from start of the insulin infusion with a variable rate infusion of glucose based on plasma glucose determinations (18) every 2.5-5 min (17). Plasma insulin concentrations were measured by radioimmunoassay using Herbert's modification (19) in arterialized venous blood samples taken at 0,30 , 60,90 , and $120 \mathrm{~min}$. The [3- $\left.\mathrm{H}^{3}\right]$ glucose infusion was given as a bolus $(30 \mu \mathrm{Ci})$ followed by $0.3 \mu \mathrm{Ci} / \mathrm{min}$. The mean plasma glucose and insulin concentrations attained in the different studies are shown in Table II.

Whole-body glucose disposal. The appearance rate of glucose $\left(R_{\mathrm{a}}\right)$ in the plasma was calculated from the plasma $\left[3-\mathrm{H}^{3}\right]$ glucose specific activities using Steele's equations $(20,21)$. Steady-state values over the last $30 \mathrm{~min}$ of each study were used for statistical analyses. In the group that received no insulin but only somatostatin and glucose, endogenous $R_{\mathrm{a}}$ was suppressed by $22 \pm 9,40 \pm 11,47 \pm 5$, and $83 \pm 6 \%$ at glucose levels of 90,160 , 250 , and $400 \mathrm{mg} / \mathrm{dl}$, respectively. Complete suppression of endogenous $R_{\mathrm{a}}$ was found at the second lowest insulin infusion rate $\left(20 \mathrm{mU} / \mathrm{m}^{2} \cdot \mathrm{min}\right)$ at all glucose levels. At this insulin level, the rates of glucose disappearance $\left(R_{\mathrm{d}}: \mathrm{s}\right)^{2}$ for glucose were comparable regardless of whether they were determined from the infusion rate of exogenous glucose or from glucose specific activities using Steele's steady-state (20) or non-steady-state (pool fraction, 0.65 ; reference 21 ) equations ( $3.1 \pm 0.3$ vs. $2.8 \pm 0.3$ vs. $2.7 \pm 0.6$ $\mathrm{mg} / \mathrm{kg}$ body wt $/ \mathrm{min}$ at $90 \mathrm{mg} / \mathrm{dl}, 5.3 \pm 0.5$ vs. $4.7 \pm 0.5$ vs. $4.9 \pm 0.5$ at 160 $\mathrm{mg} / \mathrm{dl}, 5.8 \pm 0.7$ vs. $5.0 \pm 0.4 \mathrm{vs} .5 .1 \pm 0.7 \mathrm{mg} / \mathrm{kg}$ body wt $/ \mathrm{min}$ at $250 \mathrm{mg} /$ $\mathrm{dl}$ and $8.2 \pm 2.0$ vs. $8.8 \pm 1.1$ vs. $7.8 \pm 1.0$ at $400 \mathrm{mg} / \mathrm{dl}$, for $R_{\mathrm{d}}: \mathrm{s}$ calculated from glucose infusion rates, steady vs. non-steady-state equations, respectively). However, at higher rates of glucose disposal, the isotopically determined $R_{\mathrm{a}}: \mathrm{s}$ became negative, in keeping with the findings of Ferrannini et al. (6) and Bergman et al. (22). To avoid underestimation of $R_{\mathrm{d}}$, we used the actual glucose infusion rate as the measure of total $R_{d}$ in all groups that received an insulin infusion. Total $R_{\mathrm{d}}$ was then corrected for urinary glucose loss to reflect the actual $R_{\mathrm{d}}$ by tissues.

Forearm glucose disposal. Total forearm glucose disposal (mg/dl forearm tissue - $\mathrm{min}$ ) was determined by multiplying total forearm blood flow $(\mathrm{ml} / \mathrm{dl}$ forearm $\cdot \mathrm{min}$ ) with the arterialized-venous-blood-deep-venous-blood difference $(\mathrm{mg} / \mathrm{ml})$ for glucose. Forearm blood flow was measured using capacitance plethysmography (model 2560, UFI, Morro Bay, CA). The change in voltage induced by venous occlusion was compared with the voltage induced by injection of a standard volume into the forearm. Forearm volume was determined by water displacement. Arterialized venous and deep venous blood samples for measurement

2. Abbreviation used in this paper: $R_{\mathrm{d}}: \mathrm{s}$, rate of glucose disappearance. 
Table II. Plasma Glucose and Insulin Concentrations, and Blood Flow Rates across the Forearm during the Studies

\begin{tabular}{|c|c|c|c|c|}
\hline \multirow[b]{2}{*}{ Glucose goal } & \multicolumn{4}{|c|}{ Insulin infusion rate $\left(\mathrm{mU} / \mathrm{m}^{2} \cdot \mathrm{min}\right)$} \\
\hline & 0 & 20 & 60 & 400 \\
\hline \multicolumn{5}{|l|}{$90 \mathrm{mg} / \mathrm{dl}$} \\
\hline SSPG $m g / d l$ & $91 \pm 2$ & $90 \pm 1$ & $89 \pm 1$ & $90 \pm 1$ \\
\hline SSPG-CV* \% & $3 \pm 1$ & $2 \pm 1$ & $3 \pm 1$ & $2 \pm 1$ \\
\hline SSPI $\mu U / m l$ & $7 \pm 2$ & $45 \pm 1$ & $170 \pm 14$ & $1,710 \pm 251$ \\
\hline SSPI-CV $\%$ & $15 \pm 6$ & $4 \pm 1$ & $9 \pm 3$ & $3 \pm 1$ \\
\hline Flow $\mathrm{ml} / \mathrm{dl} \cdot \min$ & $2.6 \pm 0.3$ & $2.6 \pm 0.4$ & $3.1 \pm 0.3$ & $3.0 \pm 0.3$ \\
\hline \multicolumn{5}{|l|}{$160 \mathrm{mg} / \mathrm{dl}$} \\
\hline SSPG $m g / d l$ & $160 \pm 2$ & $159 \pm 2$ & $157 \pm 3$ & $161 \pm 1$ \\
\hline SSPG-CV \% & $3 \pm 1$ & $3 \pm 1$ & $4 \pm 1$ & $2 \pm 1$ \\
\hline SSPI $\mu U / m l$ & $7 \pm 1$ & $47 \pm 2$ & $165 \pm 9$ & $2,018 \pm 184$ \\
\hline SSPI-CV \% & $20 \pm 5$ & $7 \pm 3$ & $10 \pm 3$ & $2 \pm 2$ \\
\hline Flow $\mathrm{ml} / \mathrm{dl} \cdot \min$ & $3.0 \pm 0.2$ & $2.4 \pm 0.1$ & $3.4 \pm 0.2$ & $3.1 \pm 0.4$ \\
\hline \multicolumn{5}{|l|}{$250 \mathrm{mg} / \mathrm{dl}$} \\
\hline SSPG $m g / d l$ & $259 \pm 3$ & $253 \pm 4$ & $247 \pm 4$ & $255 \pm 3$ \\
\hline SSPG-CV \% & $2 \pm 1$ & $2 \pm 1$ & $2 \pm 1$ & $3 \pm 1$ \\
\hline SSPI $\mu U / m l$ & $10 \pm 2$ & $48 \pm 4$ & $162 \pm 10$ & $1,800 \pm 241$ \\
\hline SSPI-CV \% & $7 \pm 5$ & $10 \pm 4$ & $15 \pm 4$ & $4 \pm 1$ \\
\hline Flow $\mathrm{ml} / \mathrm{dl} \cdot \min$ & $2.8 \pm 0.2$ & $2.4 \pm 0.2$ & $3.0 \pm 0.2$ & $3.5 \pm 0.6$ \\
\hline \multicolumn{5}{|l|}{$400 \mathrm{mg} / \mathrm{dl}$} \\
\hline SSPG $m g / d l$ & $402 \pm 5$ & $431 \pm 6$ & $405 \pm 11$ & $424 \pm 10$ \\
\hline SSPG-CV \% & $2 \pm 1$ & $2 \pm 1$ & $2 \pm 1$ & $4 \pm 1$ \\
\hline SSPI $\mu U / m l$ & $10 \pm 2$ & $48 \pm 4$ & $169 \pm 10$ & $1,731 \pm 285$ \\
\hline SSPI-CV \% & $28 \pm 6$ & $5 \pm 2$ & $10 \pm 2$ & $8 \pm 1$ \\
\hline Flow $\mathrm{ml} / \mathrm{dl} \cdot \min$ & $3.3 \pm 0.2$ & $3.5 \pm 0.5$ & $3.2 \pm 0.2$ & $3.4 \pm 0.6$ \\
\hline
\end{tabular}

* Coefficient of variation of plasma glucose.

${ }^{\ddagger}$ Coefficient of variation of serum insulin (mean \pm SEM of $30,60,90$, and 120 -min values).

of plasma glucose and glucose specific activities (23) were obtained simultaneously and at $90,100,110$, and $120 \mathrm{~min}$ in each study. Plasma glucose values were converted to whole blood values by multiplying the plasma value with $1-0.30 \times$ hematocrit (24). Before and during blood sampling, blood flow to the hand was interrupted for $2 \mathrm{~min}$ by a pediatric blood pressure cuff inflated to $250 \mathrm{mmHg}$. Blood flow was measured immediately after blood withdrawal.

The amount of glucose taken up by forearm muscle was calculated based on the following experiments and assumptions.

(a) Muscle mass. In six separate subjects, the percent muscle by volume in forearm was determined by computerized planimetry (Hipad Digitalizer, Houston Instrument Co., Austin, TX) from serial nuclear magnetic resonance (NMR) scans covering the section of the forearm between the blood pressure cuffs. The percent muscle in forearm was related to the percent fat-free mass (100 - \% fat [underwater weighing]) as follows: $\%$ muscle in forearm $=-4.090+0.745 \times(\%$ fat-free mass) $(r=0.79, P<0.05)$. In the 22 subjects with a mean percent fat of $14.5 \%$ (range, 5.0-29.0\%) the mean of the predicted percent muscle in forearm was $59.6 \%$ (range, $48.7-66.7 \%$ ).

(b) Flow. The blood flow in forearm muscle follows the function: muscle flow $=0.47 \times$ total forearm flow $+0.83(25)$.

Data analysis. The dose-response curves for $R_{\mathrm{d}}$ vs. glucose were fitted to a four-parameter logistic equation using a least mean square iterative routine (26): $R_{\mathrm{d}}=\left(\mathrm{a}-V_{\max }\right) /\left(1+\left[\mathrm{G} / K_{\mathrm{s}}\right]^{\mathrm{b}}\right)+V_{\max }$, where $\mathrm{a}=$ response at 0 glucose, $V_{\max }=$ response at an infinite glucose concentration, $K_{\mathrm{s}}$ $=$ the $50 \%$ maximally efficient dose. $\mathrm{b}=$ slope factor and $\mathrm{G}=$ plasma glucose concentration. If $\mathrm{b}=1$, the above equation equals the MichaelisMenten equation: $R_{\mathrm{d}}=\left(V_{\max }\right) \times(\mathrm{G}) /\left(\left(K_{\mathrm{q}}+[\mathrm{G}]\right)\right.$.
Before searching for the best fit for the observed means, nonuniformity of the variance of the response was estimated by a weighing function (26). Groups of dose-response pairs (glucose concentration followed by individual values for rates of glucose disposal) were then entered to obtain the best fit at each insulin concentration. Goodness of fit was evaluated on the basis of residual variance, by the use of the extra sum of squares principle. Deviations of observed responses from predicted responses was tested by the number of "runs" of positive or negative residuals (26). For each observed best fit, the data points were randomly distributed (i.e., "runs" test $>0.05$ ) around the fitted curve, indicating appropriateness of the model. The program described by DeLean et al. for simultaneously fitting several dose-response curves based on the four-parameter logistic equation allows rigid statistical analysis of shared parameters for several curves without having to predefine any of the parameters (26). We did, however, assume a to be zero, i.e., glucose disposal to be zero in the absence of glucose. Comparison of means was done by the paired or unpaired Student's $t$ test after one-way analysis of variance or analysis of variance for repeated measures, respectively.

\section{Results}

\section{Whole-body glucose disposal}

Insulin $\sim 9 \mu \mathrm{U} / \mathrm{ml}$. At the lowest insulin level, the best fit for whole-body $R_{\mathrm{d}}: \mathrm{s}$ over the glucose range $90-400 \mathrm{mg} / \mathrm{dl}$ was compatible with the Michaelis-Menten equation. The predicted $K_{\mathrm{s}}$ and $V_{\max }$ were $8.7 \pm 1.1 \mathrm{mM}$ and $6.4 \pm 0.5 \mathrm{mg} / \mathrm{kg} \cdot \min$ (Fig. 3).

Insulin $\sim 50 \mu \mathrm{U} / \mathrm{ml}$. The $K_{\mathrm{s}}$ and $V_{\max }$ averaged $19.8 \pm 9 \mathrm{mM}$ and $17.0 \pm 5.8 \mathrm{mg} / \mathrm{kg} \cdot \mathrm{min}$, respectively (Fig. 3). As shown in Fig. 3, the observed increase in $R_{d}$ as a function of plasma glucose was less than expected, assuming a $V_{\max }$ of $17.0 \mathrm{mg} / \mathrm{kg} \cdot \min$ and an unchanged $K_{\mathrm{s}}$ similar to that observed at the lowest insulin level $(8.7 \mathrm{mM})$. The goodness of fit for the data assuming a $K_{\mathrm{s}}$ of $8.7 \mathrm{mM}$ instead of the observed $K_{\mathrm{s}}$ of $19.8 \mathrm{mM}$ differed almost significantly from the best fit $(P=0.06$, Table III).

Insulin $\sim 160 \mu \mathrm{U} / \mathrm{ml}$. The $K_{\mathrm{s}}(24.8 \pm 7.4 \mathrm{mM})$ at this insulin level was significantly $(P<0.05)$ higher than that found at the lowest insulin level. Consequently, the observed $R_{\mathrm{d}}: \mathrm{s}$ were lower than what would be predicted for an unchanged $K_{\mathrm{s}}$ (Fig. 3 ). The best fit for the data was different $(P<0.02)$ from the fit where $K_{\mathrm{s}}$ was constrained to $8.7 \mathrm{mM}$ and $V_{\max }$ was constrained to the predicted $43.3 \pm 8.1 \mathrm{mg} / \mathrm{kg} \cdot \min$ (Table III).

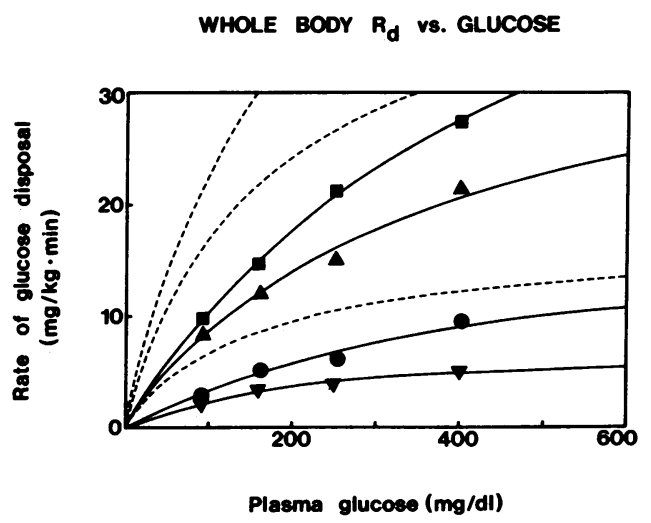

Figure 3. Whole-body glucose disposal vs. plasma glucose at different insulin levels. ( $\boldsymbol{\nabla}),(\bullet),(\Delta),(\bullet)$ Mean rates of glucose disposal at insulin levels of $\sim 9, \sim 50, \sim 160$ and $\sim 1,700 \mu \mathrm{U} / \mathrm{ml}$, respectively. Solid lines depict the best fits for the data; dashed lines depict fits for the data assuming a constant $K_{\mathbf{z}}$ similar to that found at the lowest insulin level $(8.7 \mathrm{mM})$. 
Table III. Tests for Goodness of Fits of Rates of Whole-Body Glucose Disposal vs. Plasma Glucose Using a Four-Parameter Logistic Function at Insulin Levels of $\sim 50, \sim 160$, and $\sim 1,700 \mu \mathrm{U} / \mathrm{ml}$

\begin{tabular}{|c|c|c|c|c|}
\hline \multicolumn{2}{|l|}{ Whole body $R_{d}$} & \multirow[b]{2}{*}{ Parameters } & \multirow[b]{2}{*}{ F test * } & \multirow{2}{*}{$\begin{array}{l}\text { Significance } \\
\text { vs. best fit }\end{array}$} \\
\hline Insulin & Fit & & & \\
\hline \multirow[t]{3}{*}{$50 \mu \mathrm{U} / \mathrm{ml}$} & A & $\begin{array}{l}\mathrm{a}^{\ddagger}=0 \\
\mathrm{~b}^{\S}=1.1\end{array}$ & - & \\
\hline & B & $\begin{array}{l}\mathrm{a}=0 \\
\mathrm{~b}=1.0 \\
K_{\mathrm{s}}=19.8 \mathrm{mM} \\
V_{\max }=17.0 \mathrm{mg} / \mathrm{kg} \cdot \min \end{array}$ & 0.44 & NS \\
\hline & $\mathrm{C}$ & $\begin{array}{l}\mathrm{a}=0 \\
\mathrm{~b}=1.0 \\
K_{\mathrm{s}}=8.7 \mathrm{mM} \\
V_{\max }=17.0 \mathrm{mg} / \mathrm{kg} \cdot \min \end{array}$ & 15.4 & $P<0.1$ \\
\hline \multirow[t]{3}{*}{$\sim 160 \mu \mathrm{U} / \mathrm{ml}$} & A & $\begin{array}{l}a=0 \\
b=0.9\end{array}$ & - & \\
\hline & B & $\begin{array}{l}\mathrm{a}=0 \\
\mathrm{~b}=1.0 \\
K_{\mathrm{s}}=24.8 \mathrm{mM} \\
V_{\max }=43.3 \mathrm{mg} / \mathrm{kg} \cdot \min \end{array}$ & 6.4 & NS \\
\hline & $\mathrm{C}$ & $\begin{array}{l}\mathrm{a}=0 \\
\mathrm{~b}=1.0 \\
K_{\mathrm{s}}=8.7 \mathrm{mM} \\
V_{\max }=43.3 \mathrm{mg} / \mathrm{kg} \cdot \min \end{array}$ & 79.8 & $P<0.02$ \\
\hline \multirow[t]{3}{*}{$\sim 1,700 \mu \mathrm{U} / \mathrm{ml}$} & A & $\begin{array}{l}a=0 \\
b=1.0\end{array}$ & & \\
\hline & B & $\begin{array}{l}\mathrm{a}=0 \\
\mathrm{~b}=1.0 \\
K_{\mathrm{s}}=25.9 \mathrm{mM} \\
V_{\max }=59.6 \mathrm{mg} / \mathrm{kg} \cdot \min \end{array}$ & 0 & NS \\
\hline & $\mathrm{C}$ & $\begin{array}{l}\mathrm{a}=0 \\
\mathrm{~b}=1.0 \\
K_{\mathrm{s}}=8.7 \mathrm{mM} \\
V_{\max }=59.6 \mathrm{mg} / \mathrm{kg} \cdot \min \end{array}$ & 419.2 & $P<0.005$ \\
\hline
\end{tabular}

Best fit $(A)$ is compared with a fit that follows Michaelis-Menten kinetics, i.e., b $=1$, with the observed $K_{\mathrm{s}}(B)$ or with a $K_{\mathrm{s}}$ similar to that observed at the lowest insulin concentration $(C)$. Unconstrained curve fitting or fitting assuming only a $=0$ resulted in inappropriate fits as judged from the randomness of residuals tested by the "runs" test (26) of positive or negative residuals. Therefore, the best fit for the least constrained curve ( $a$ and $b$ constrained) was used as a basis for the $F$ tests. ${ }^{*} \mathrm{~F}$ ratio reflects gain in the number of degrees of freedom vs. gain in the number of the sum of squares of residuals. A small $F(\sim 1)$ indicates appropriateness of the constraints $\left(\mathrm{a}, \mathrm{b}, K_{\mathbf{s}}, V_{\max }\right)$.

${ }^{\ddagger} \mathrm{a}=$ rate of glucose disposal at the plasma glucose concentration 0 $\mathrm{mg} / \mathrm{dl}$.

${ }^{\S} \mathrm{b}=$ slope factor (if $\mathrm{b}=1$, the four-parameter equation becomes the Michaelis-Menten equation).

Insulin $\sim 1700 \mu U / \mathrm{ml}$. The apparent $K_{\mathrm{s}}$ for glucose disposal averaged $25.9 \pm 5 \mathrm{mM}$, which was significantly $(P<0.01)$ higher than that observed at the lowest insulin level (Fig. 3). Also, the best fit for the data was different $(P<0.005)$ from the fit assuming an unchanged $K_{\mathrm{s}}$ (Table III). The predicted $V_{\max }$ was $59.6 \pm 7.5$ $\mathrm{mg} / \mathrm{kg} \cdot \mathrm{min}$.

\section{Forearm glucose disposal}

Glucose disposal by the forearm followed in general the same pattern as at the level of the whole body (Fig. 4). Thus, in the basal state the $K_{\mathrm{s}}(7.4 \pm 1.4 \mathrm{mM})$ was compatible with a $K_{\mathrm{s}}$ for the transport system. At higher insulin levels, the process determining the rate of glucose disposal had a lower apparent affinity for glucose $\left(K_{\mathrm{s}}: \mathrm{s} 18.1 \pm 7.5,16.2 \pm 9.2,37.7 \pm 20.7 \mathrm{mM}\right.$ at insulin levels of $\sim 50,160$, and $1,700 \mu \mathrm{U} / \mathrm{ml}, P<0.05$ vs. basal) than what would have been predicted if glucose disposal followed Michaelis-Menten kinetics with an unchanged $K_{\mathrm{s}}$ (Fig. 4, Table IV). Neither insulin nor glucose changed the rate of blood flow across the forearm (Table II).

The fraction of total glucose $R_{\mathrm{d}}$ attributable to total body muscle tissue extrapolated from forearm muscle averaged $33 \pm 6 \%$ at the lowest insulin and glucose level. At the next glucose level $(160 \mathrm{mg} / \mathrm{dl})$ at the lowest insulin level, this fraction was $70 \pm 10 \%$. At all higher glucose or insulin levels, this fraction remained constant and averaged $68 \pm 3 \%$. The correlation coefficient between total body glucose disposal and forearm glucose disposal was $0.87(P<0.001$; Fig. 5).

\section{Discussion}

Study of glucose kinetics in the whole body is complicated by several methodological problems. First, neither very low nor maximal glucose disposal rates can be accurately determined because only a narrow range of glucose concentrations can be used in vivo. Second, initial rates of glucose disposal are difficult to measure because of the time required for glucose and insulin to reach the insulin-sensitive tissues and for insulin to exert its action. Even so, concentrations of insulin and glucose at the tissue level may not reflect those in plasma. Finally, glucose kinetics in whole body represents the kinetic behavior of several rather than one tissue. Despite these limitations, Gottesman et al. (5) proposed that whole-body glucose disposal both in the basal state and during insulin stimulation follows saturation kinetics of the Michaelis-Menten type and has a $K_{\mathrm{s}}$ characteristic of the glucose transport system (6-12 mM, 5, 27-29). However, in the study of Gottesman et al. (5), saturation could not be demonstrated. The way glucose disposal was predicted to approach saturation beyond the glucose range studied is shown in Fig. 1. In the present study, when measured over a wide range of glucose and insulin concentrations, glucose disposal rates did

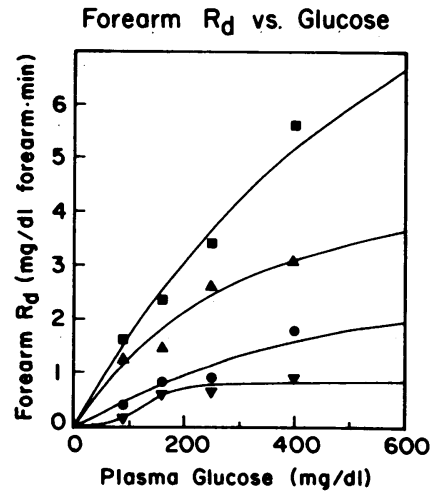

Figure 4. Glucose disposal by forearm vs. plasma glucose. ( $\nabla)$ $(\bullet),(\Delta),(\bullet)$ Mean glucose disposal rates at insulin levels of $\sim 9, \sim 50, \sim 160$, and $\sim 1,700 \mu \mathrm{U} / \mathrm{ml}$, respectively. Lines depict the best fit for the glucose disposal rates at various insulin levels. 
Table IV. Tests for Goodness of Fits for Rates of

Forearm Glucose Disposal vs. Plasma Glucose at Insulin Levels of $\sim 50, \sim 160$, and $\sim 1,700 \mu \mathrm{U} / \mathrm{ml}$

\begin{tabular}{|c|c|c|c|c|}
\hline \multicolumn{2}{|l|}{ Forearm $R_{\mathbb{d}}$} & \multirow[b]{2}{*}{ Parameters } & \multirow[b]{2}{*}{$F$ test } & \multirow[b]{2}{*}{$\begin{array}{l}\text { Significance } \\
\text { vs. best fit }\end{array}$} \\
\hline Insulin & Fit & & & \\
\hline \multirow[t]{3}{*}{$\sim 50 \mu \mathrm{U} / \mathrm{ml}$} & $\mathbf{A}$ & $\begin{array}{l}a=0 \\
b=1.4\end{array}$ & & \\
\hline & B & $\begin{array}{l}\mathrm{a}=0 \\
\mathrm{~b}=1.0 \\
K_{\mathrm{s}}=18.1 \mathrm{mM} \\
V_{\max }=2.79 \mathrm{mg} / \mathrm{dl} \cdot \min \end{array}$ & 2.2 & NS \\
\hline & $\mathrm{C}$ & $\begin{array}{l}\mathrm{a}=0 \\
\mathrm{~b}=1.0 \\
K_{\mathrm{s}}=7.4 \mathrm{mM} \\
V_{\max }=2.79 \mathrm{mg} / \mathrm{dl} \cdot \min \end{array}$ & 11.3 & $P<0.1$ \\
\hline \multirow[t]{3}{*}{$\sim 160 \mu \mathrm{U} / \mathrm{ml}$} & $\mathbf{A}$ & $\begin{array}{l}a=0 \\
b=1.1\end{array}$ & & \\
\hline & B & $\begin{array}{l}\mathrm{a}=0 \\
\mathrm{~b}=1.0 \\
K_{\mathrm{s}}=16.2 \mathrm{mM} \\
V_{\max }=5.26 \mathrm{mg} / \mathrm{dl} \cdot \min \end{array}$ & 0.1 & NS \\
\hline & $\mathrm{C}$ & $\begin{array}{l}\mathrm{a}=0 \\
\mathrm{~b}=1.0 \\
K_{\mathrm{s}}=7.4 \mathrm{mM} \\
V_{\max }=5.26 \mathrm{mg} / \mathrm{dl} \cdot \min \end{array}$ & 8.3 & $P<0.1$ \\
\hline \multirow[t]{3}{*}{$\sim 1,700 \mu \mathrm{U} / \mathrm{ml}$} & A & $\begin{array}{l}a=0 \\
b=1.0\end{array}$ & & \\
\hline & B & $\begin{array}{l}\mathrm{a}=0 \\
\mathrm{~b}=1.0 \\
K_{\mathrm{s}}=37.7 \mathrm{mM} \\
V_{\max }=13.4 \mathrm{mg} / \mathrm{dl} \cdot \min \end{array}$ & 0 & NS \\
\hline & $\mathrm{C}$ & $\begin{array}{l}\mathrm{a}=0 \\
\mathrm{~b}=1.0 \\
K_{\mathrm{z}}=7.4 \mathrm{mM} \\
V_{\max }=13.4 \mathrm{mg} / \mathrm{dl} \cdot \min \end{array}$ & 37.3 & $P<0.05$ \\
\hline
\end{tabular}

For explanation of abbreviations see Table III.

not follow the Michaelis-Menten equation with a constant $K_{\mathrm{s}}$ in the range proposed by Gottesman et al. (5) except in the presence of a low insulin level $(9 \mu \mathrm{U} / \mathrm{ml})$ and at low rates of glucose disposal $(2-5 \mathrm{mg} / \mathrm{kg} \cdot \mathrm{min})$. At the higher insulin levels and rates of glucose disposal, the apparent $K_{\mathrm{s}}$ increased significantly, a finding which clearly contradicts the prediction of a constant $K_{\mathbf{s}}$ by Gottesman et al. (5). Recently, Fink et al. (27) examined the effect of hyperglycemia on in vivo glucose disposal in elderly and young subjects at an insulin concentration of $\sim 100 \mu \mathrm{U} / \mathrm{ml}$. The mean rate of glucose disposal at $250 \mathrm{mg} / \mathrm{dl}$ was not significantly different from that at a glucose concentration of $350 \mathrm{mg} / \mathrm{dl}$ (27). Based on this lack of difference in the mean rates of glucose disposal, Fink et al. (27) then assumed that glucose disposal was maximal at $350 \mathrm{mg} / \mathrm{dl}$ and obtained $K_{\mathrm{s}}: \mathrm{s}$ of $100 \mathrm{mg} / \mathrm{dl}$ by calculating the concentration of glucose
$R_{d}$ Whole Body vs. Forearm

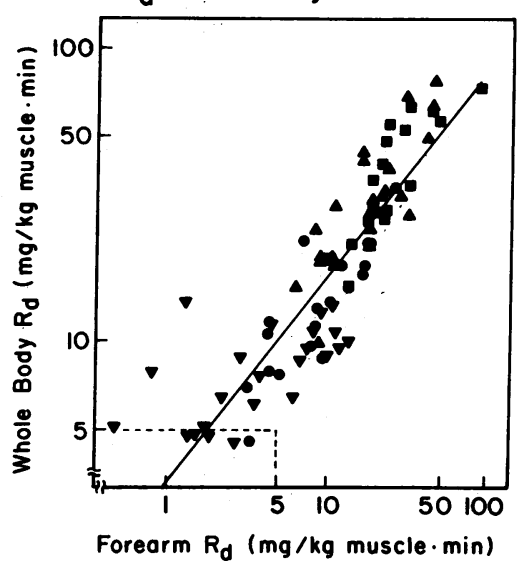

Figure 5. Relationship between forearm glucose uptake and whole-body glucose uptake. $(\nabla),(\bullet)$, (4), (ם) Individual values at insulin levels of $\sim 9$, $\sim 50, \sim 160$, and tively. $\sim 1,700 \mu \mathrm{U} / \mathrm{ml}$, respec-

required to stimulate glucose disposal $50 \%$ of the rate found at the glucose concentration of $350 \mathrm{mg} / \mathrm{dl}$. When Fink et al. (27) analyzed their data more rigorously, i.e., by not assuming that glucose disposal was maximal at $350 \mathrm{mg} / \mathrm{dl}$ and by using EadieHofstee plots, the $K_{\mathrm{s}}: \mathrm{s}$ were $\sim 300 \mathrm{mg} / \mathrm{dl}(17 \mathrm{mM})$ in both groups. These $K_{\mathrm{s}}$ values are approximately twofold higher than those predicted by Gottesman et al. (5) using lower glucose concentrations but comparable with those found in the present study (20 and $25 \mathrm{mM}$ at insulin concentrations of 50 and 160 $\mu \mathrm{U} / \mathrm{ml})$.

To avoid some of the problems associated with measurement of glucose kinetics at the level of the whole body, we also determined glucose disposal rates across the forearm. This technique has been used to measure substrate fluxes across a muscle bed. Extrapolation from forearm glucose uptake to total muscle uptake is based on several assumptions including the estimation of blood flow distribution in forearm tissues and the determination of muscle mass in both the forearm and the whole body. Errors in these estimations lead to imprecise estimates of glucose disposal rates. The use of arterialized venous blood as a substitute for true arterial blood has become widely accepted although the arterial glucose concentration has been found to be $\sim 0.5-2 \%$ $(14,15)$ higher than the glucose concentration in arterialized venous blood at a glucose concentration of $\sim 90 \mathrm{mg} / \mathrm{dl}(14,15)$. In the study of McGuire et al. (15), the fractional loss of glucose ( $\sim 2 \%$ ) was found to be unaffected by hyperglycemia (hyperglycemic clamp; glucose, $220 \mathrm{mg} / \mathrm{dl}$ ). If our results are recalculated assuming that the heated vein glucose concentration was $2 \%$ lower than the arterial glucose concentration over the whole range of glucose concentrations, the $K_{8}: s$ at the lowest and highest insulin concentration would be 9.9 and $26.4 \mathrm{mM}$, respectively, i.e., not different from the estimates obtained using the measured heated vein glucose concentrations of 8.7 and $25.8 \mathrm{mM}$. Thus, the effect of the difference in the glucose concentration between arterial and arterialized venous blood on our results seems to be small, however, it should be noted that there are no data of the magnitude of the difference above the glucose concentration $220 \mathrm{mg} / \mathrm{dl}$.

Regarding the possible error in muscle mass estimation, in addition to determining fat-free mass by underwater weighing, we determined the muscle content of the forearm in six subjects by sequential NMR scanning to obtain an equation that would allow us to correct for individual variations in forearm muscle content instead of using a fixed value. Our estimate of the mean 
fraction of forearm made up of muscle tissue (0.60) is similar to the value found in dissection studies of five forearms by Cooper et al. (0.63) (25). Although leg muscle might be more representative of whole body muscle than forearm muscle because of its larger mass, it was ethically impossible to perform repeated femoral vein catheterization measurements in our volunteers. Furthermore, when the amount of glucose taken up by forearm muscle was extrapolated to total body muscle, muscle tissue accounted for $70 \%$ of total body glucose disposal, an estimate slightly lower but relatively close to that $(85 \%)$ found by DeFronzo et al. (1) from leg vs. whole-body glucose disposal measurements. When the kinetic constants were estimated across the forearm, they corresponded to those seen in the whole body. At all insulin levels except the basal, glucose disposal increased almost linearly with increasing glucose concentration and thus did not follow the expected Michaelis-Menten equation (Fig. 7).

Our finding of a $K_{\mathrm{s}}$ characteristic of the glucose transport system in muscle $(6-11 \mathrm{mM} ; 28-30)$ at low rates of glucose disposal is compatible with glucose transport being rate-limiting for glucose disposal. The apparent increase in the $K_{\mathrm{s}}$ at higher rates of glucose disposal could be due to a decrease in the affinity of the glucose transport system for glucose. However, in in vitro studies in muscle $(3,4)$ as well as other tissues $(31)$, the stimulation of glucose transport activity by insulin has been shown to occur through an increase of the maximum transport velocity rather than a change in the apparent affinity of the carrier for glucose. In a few studies in adipocytes (32) and muscle (33), insulin has been reported to both increase the apparent affinity (decrease the $K_{\mathrm{s}}$ ) of the transporter for glucose and increase the maximum velocity. Thus, it is unlikely that the increase in the apparent $K_{\mathrm{s}}$ observed in the present study reflects a change in the affinity of the glucose transport system. Rather we would suggest that the apparent increase in the $K_{\mathrm{s}}$ reflects a shift in the rate-limiting step from glucose transport to some step beyond transport.

Our conclusion that glucose transport cannot be rate limiting under hyperinsulinemic conditions is in agreement with the early studies of Morgan et al. $(30,34,35)$ in the perfused rat heart and the more recent findings in the rat hindlimb (11). In the studies of Morgan et al. (30, 34, 35), glucose disposal in the absence of insulin reached a plateau above $300 \mathrm{mg} / \mathrm{dl}$ perfusate concentrations and had a $K_{\mathrm{s}}$ of $9 \mathrm{mmol} /$ liter. Under these conditions, only very low levels of intracellular free glucose were present. During insulin stimulation, glucose disposal showed less of a tendency to reach a plateau at high concentrations of glucose, and the $K_{\mathrm{s}}$ increased about threefold to $25 \mathrm{mmol} / \mathrm{liter}$ due to a shift on the rate-limiting step from transport to phosphorylation. Recently, a shift in the rate-limiting step was also demonstrated in rat skeletal muscle (6) using a kinetic approach to resolve the rate-limiting step for glucose disposal. In the perfused rat hindlimb, glucose disposal plateaued rapidly in the absence of insulin at a glucose level of $\sim 140 \mathrm{mg} / \mathrm{dl}$. At submaximally or maximally stimulating insulin concentrations, however, glucose disposal had not reached its maximum at $400 \mathrm{mg} / \mathrm{dl}$ (11). These findings are almost identical to those found in the present study across the forearm: a plateau in glucose disposal in the basal state was reached at glucose levels of $\sim 160-200 \mathrm{mg} / \mathrm{dl}$, whereas at submaximal or at maximal insulin levels glucose disposal showed no tendency to saturate even at $400 \mathrm{mg} / \mathrm{dl}$ (Fig. 4). Because saturation should occur at the same glucose level and $K_{\mathrm{s}}$ should be constant at each insulin level if glucose disposal followed Michaelis-Menten kinetics, these data obviously are incompatible with the view of glucose transport is rate limiting during hyperinsulinemic conditions. We cannot, however, exclude the possibility that some step beyond transport is rate limiting already at the lowest insulin level over the range of glucose concentrations used to determine glucose disposal. In the rat hindlimb, where initial glucose transport rates could be determined both in the absence and presence of insulin, glucose transport was not rate limiting in the absence of insulin under hyperglycemic conditions (glucose $>160 \mathrm{mg} / \mathrm{dl}$ ) (11). Because it is not possible to measure glucose disposal rates at low glucose concentrations in man, we cannot be sure whether saturation of glucose disposal at the lowest insulin level was due to saturation of glucose transport or some intracellular pathway.

A change in the rate-limiting step for glucose disposal is also in agreement with the recent findings of Ferrannini et al. (6), who used a physiological compartmental model to describe kinetics of glucose in normal man in the basal state and under steady-state conditions of euglycemic hyperinsulinemia. The distribution space of glucose in the slow pool reflecting insulinsensitive tissues was found to be rate dependent; at high $(>6$ $\mathrm{mg} / \mathrm{kg} \cdot \mathrm{min}$ ) rates of glucose disposal the exchangeable mass of glucose was markedly increased, suggesting the accumulation of free intracellular glucose. However, in vitro studies in rat muscle and measurements of intracellular glucose during insulin stimulation have yielded conflicting results. When the glucose space has been calculated from the ratio of glucose in plasma water vs. muscle tissue, no increase has been found $(7,8)$. On the other hand, the question of whether the possible increase in intracellular glucose actually is measurable with this approach has not been addressed in these studies $(7,8)$. For example, the intracellular water available for glucose distribution in muscle has not been determined $(7,8)$. In adipocytes, an intracellular diffusion barrier seems to exist between the transport site and the site of phosphorylation $(9,36)$, but whether similar compartmentalization exists in muscle is unknown. In the perfused rat heart (35), insulin increased the muscle glucose space. Whether the difference in the type of muscle, its capillary supply, or the methods used to determine the glucose space in the muscle cell or some other factor(s) account for these divergent findings regarding accumulation of intracellular glucose has not been resolved.

In summary, glucose disposal in the basal state could be described with saturation kinetics of the Michaelis-Menten type with a $K_{\mathrm{s}}$ similar to that characterizing the glucose transport system in many mammalian cells. During insulin stimulation, the $K_{\mathrm{s}}$ for glucose utilization increases. Because at present there is no evidence suggesting that insulin increases the $K_{\mathrm{s}}$ of the glucose transport system, we interpret the apparent increase in $K_{\mathrm{s}}$ to reflect a shift in the rate-limiting step from glucose transport to some step beyond transport.

\section{Acknowledgments}

We thank the nursing staff for their professional care of the subjects while on the research ward and for their assistance with many of the procedures. We thank our technical staff for assistance.

\section{References}

1. DeFronzo, R. A., E. Jacot, E. Jequier, E. Maeder, J. Wahren, and J. P. Felber. 1981. The effect of insulin on the disposal of intravenous glucose. Results from indirect calorimetry and hepatic and femoral venous catheterization. Diabetes. 30:1000-1007. 
2. Bogardus, C., S. Lillioja, K. Stone, and D. Mott. 1984. Correlation between muscle glycogen synthase activity and in vivo insulin action in man. J. Clin. Invest. 73:1185-1190.

3. Narahara, H. T., and P. Özand. 1963. Studies of tissue permeability. IX. The effect of insulin on the penetration of 3-methylglucose- $\mathrm{H}^{3}$ in frog muscle. J. Biol. Chem. 238:40-49.

4. Wardzala, L. J., and B. Jeanrenaud. 1981. Potential mechanism of insulin action on glucose transport in the isolated rat diaphragm. $J$. Biol. Chem. 256:7090-7093.

5. Gottesman, I., L. Mandarino, C. Verdonk, R. Rizza, and J. Gerich. 1982. Insulin increases the maximum velocity for glucose uptake without altering the Michaelis constant in man. J. Clin. Invest. 70:1310-1314.

6. Ferrannini, E., J. D. Smith, C. Cobelli, G. Toffolo, A. Pilo, and R. A. DeFronzo. 1985. Effect of insulin on the distribution and disposition of glucose in man. J. Clin. Invest. 76:357-364.

7. Kipnis, D. M., E. Helmreich, and C. F. Cori. 1959. Studies of tissue permeability. IV. The distribution of glucose between plasma and muscle. J. Biol. Chem. 234:165-170.

8. Goodman, M. N., M. Berger, and N. B. Ruderman. 1974. Glucose metabolism in rat skeletal muscle at rest. Diabetes. 23:881-888.

9. Foley, J. E., S. W. Cushman, and L. B. Salans. 1980. Intracellular glucose concentration in small and large rat adipose cells. Am. J. Physiol. 238:E180-E185.

10. Lynch, R. M., and R. J. Paul. 1986. Compartmentation of carbohydrate metabolism in vascular smooth muscle: evidence for at least two functionally independent pools of glucose-6-phosphate. Biochim. Biophys. Acta. 887:315-318.

11. Kubo, K., and J. E. Foley. 1986. Rate-limiting steps for insulinmediated glucose uptake into perfused rat hindlimb. Am. J. Physiol. 250:E100-E102.

12. National Diabetes Data Group. 1979. Classification and diagnosis of diabetes mellitus and other categories of glucose intolerance. Diabetes. 28:1039-1057.

13. Goldman, R. F., and E. R. Buskirk. 1961. A method for underwater weighing and the determination of body density. In Techniques for Measuring Body Composition. J. Brozek and A. Herschel, editors. National Academy of Science, National Research Council, Wash. DC. 78-89.

14. Abumrad, N. N., D. Rabin, M. P. Diamond, and W. W. Lacy. 1981. Use of a heated superficial hand vein as an alternative site for the measurements of amino acid concentrations and for the study of glucose and alanine kinetics in man. Metabolism. 30:936-940.

15. McGuire, E. A. H., J. H. Helderman, J. D. Tobin, R. Andres, and M. Berman. 1976. Effects of arterial versus venous sampling on analysis of glucose kinetics in man. J. Appl. Physiol. 41:565-573.

16. Coles, D. R., K. E. Cooper, R. F. Mottram, and J. V. Occleshaw. 1958. The source of blood samples withdrawn from deep forearm veins via catheters passed upstream from the median cubital vein. J. Physiol. 142:323-328.

17. DeFronzo, R. A., J. D. Tobin, and R. Andres. 1979. Glucose clamp technique: a method for quantifying insulin secretion and resistance. Am. J. Physiol. 237:E214-E223.

18. Kadish, A. H., R. L. Little, and J. C. Sternberg. 1968. A new and rapid method for the determination of glucose by measurement of rate of oxygen consumption. Clin. Chem. 14:116-131.
19. Herbert, V., K. Lau, C. W. Gottlieb, and S. J. Bleicher. 1965. Coated charcoal immunoassay for insulin. J. Clin. Endocrinol. \& Metab. 25:1375-1384.

20. Steele, R., J. S. Wall, R. C. DeBodo, and N. Altszuler. 1956. Measurement of size and turnover rate of body glucose pool by the isotope dilution method. Am. J. Physiol. 187:15-24.

21. Radziuk, J., K. H. Norwich, and M. Vranic. 1978. Experimental validation of measurements of glucose turnover in nonsteady-state. Am. J. Physiol. 234:E84-E93.

22. Bergman, R. N., D. T. Finegood, and M. Ader. 1985. Assessment of insulin sensitivity in vivo. Endocrine Reviews. 6:45-86.

23. Best, J. D., G. Judzewitsch, M. A. Pfeiffer, J. C. Beard, J. B. Halter, and D. Porte, Jr. 1982. The effect of chronic sulfonylurea therapy on hepatic glucose production in noninsulin-dependent diabetes mellitus. Diabetes. 31:333-338.

24. Dillon, R. S. 1965. Importance of hematocrit in interpretation of blood sugar. Diabetes. 14:672-674.

25. Cooper, K. E., O. G. Edholm, and R. F. Mottram. 1955. The blood flow in skin and muscle of the human forearm. J. Physiol. 128: 258-267.

26. DeLean, A., P. J. Munson, and D. Rodbard. 1978. Simultaneous analysis of families of sigmoidal curves: application to bioassay, radioligand assay, and physiological dose-response curves. Am. J. Physiol. 235:E97-E102.

27. Fink, R. I., P. Wallace, and J. M. Olefsky. 1986. Effects of aging on glucose-mediated glucose disposal and glucose transport. J. Clin. Invest. 77:2034-2041.

28. Narahara, H. T., P. Özand, and C. F. Cori. 1960. Studies of tissue permeability. VII. The effect of insulin on glucose penetration and phosphorylation in frog muscle. J. Biol. Chem. 235:3370-3378.

29. Post, R. L., H. E. Morgan, and C. R. Park. 1961. Regulation of glucose uptake in muscle. III. The interaction of membrane transport and phosphorylation in the control of glucose uptake. J. Biol. Chem. 236:269-272.

30. Morgan, H. E., D. M. Regen, and C. R. Park. 1964. Identification of a mobile carrier-mediated sugar transport system in muscle. J. Biol. Chem. 239:369-374.

31. Simpson, I. A., and S. W. Cushman. 1986. Hormonal regulation of mammalian glucose transport. Annu. Rev. Biochem. 55:1059-1089.

32. Whitesell, R. R., and N. A. Abumrad. 1985. Increased affinity predominates in insulin stimulation of glucose transport in the adipocyte. J. Biol. Chem. 260:2894-2899.

33. Chaudry, M. H., and M. K. Gould. 1969. Kinetics of glucose uptake in isolated soleus muscle. Biochim. Biophys. Acta. 177:528-536.

34. Park, C. R., D. Reinwein, M. J. Henderson, E. Cadenas, and H. E. Morgan. 1959. The action of insulin on the transport of glucose through the cell membrane. Am. J. Med. 26:674-684.

35. Morgan, H. E., M. J. Henderson, D. M. Regen, and C. R. Park. 1961. Regulation of glucose uptake in muscle. I. The effects of insulin and anoxia on glucose transport and phosphorylation in the isolated, perfused heart of normal rats. J. Biol. Chem. 236:253-261.

36. Foley, J. E., and J. Gliemann. 1981. Accumulation of 2-deoxyglucose against its concentration gradient in rat adipocytes. Biochim. Biophys. Acta. 648:100-106. 